\section{Effect of Khaya Senegalensis Bark and Oil on Post-Harvest Fungal Agents of Groundnut Seeds Rot in Adamawa State, Nigeria}

\author{
Channya FK*, Asama P and Anjili SM \\ Department of Plant Science, School of Life Sciences, Modibbo Adama University of Technology, \\ Yola, Nigeria
}

\section{Abstract}

Standardized method of seed treatment is of prime importance in the production of groundnut. The study was to carry out control trial using bark extract (aqueous and ethanol) and oil (seed) of mahogany (Khaya senegalensis) on seven (7) isolated fungi from two groundnut varieties (peruvian and valencia). The result shows that both mahogany bark and seed extracts are capable of inhibiting mycelial growth of all the isolates. There was no significant variation between the aqueous and ethanol bark extracts in-vitro, however the in-vivo test shows a significant difference between the aqueous and the ethanol bark extract in which the ethanol extract reduced growth of the pathogens more than the aqueous. For all the pathogens except Rhizopus stolonifer there was no growth between $50 \%$ to $100 \%$ concentration of the Khaya senegalensis oil in-vitro, however in-vivo control at $50 \%$ produced scanty to moderate growth for all the pathogens except Rhizopus stolonifer on peruvian, while there was full coverage on the seeds of valencia variety with Aspergillus niger and Rhizopus stolonifer having total coverage though Pseudaiiescheria boydii and Cylindrocarpon lichenicola were effectively inhibited and showed no growth at the $50 \%$ and $100 \%$. Further research to focus on the quantifying the chemical constituents and formulation are suggested.

\section{More Information}

*Address for Correspondence: Channya FK, Department of Plant Science, School of Life Sciences, Modibbo Adama University of Technology, Yola, Nigeria, Tel: +234 703523 8419; Email: farbinah222@gmail.com

\section{Submitted: 08 July 2019 \\ Approved: 01 August 2019 \\ Published: 02 August 2019}

How to cite this article: Channya FK, Asama P, Anjili SM. Effect of Khaya Senegalensis Bark and Oil on Post-Harvest Fungal Agents of Groundnut Seeds Rot in Adamawa State, Nigeria. J Plant Sci Phytopathol. 2019; 3: 076-080.

DOI: dx.doi.org/10.29328/journal.jpsp.1001035 Copyright: () 2019 Channya FK, et al. This is an open access article distributed under the Creative Commons Attribution License, which permits unrestricted use, distribution, and reproduction in any medium, provided the original work is properly cited

Keywords: Groundnut; Fungi; Mahogany; Bark; Seed control

\section{Check for updates}

\section{Introduction}

Groundnut (Arachis hypogaea L.) is an annual crop that belongs to Fabiaceae family and is believed to have originated from South America [1]. The crop is the $13^{\text {th }}$ most important food crop source of edible oil and the $3^{\text {th }}$ most important source of vegetable protein [2].

The production of this crop is facing a major constraint which causes losses of healthy seeds, this is as a result of the activities of fungi, bacteria, viruses, nematodes, insects and parasitic weeds [3]. However, fungi can be rated as the most harmful microorganism [2]. Several fungi were isolated from peanut pods, shells and seeds. These fungi are Aspergillus niger, Aspergillus flavus, Alternaria dianthicola, Curvularia lunata, Curvularia pellescens, Fusarium oxysporum, Fusarium equiseti, Macrophomina phaseolina, Rhizopus stolonifer, Penicillium digitatum and Penicillium chrysogenum $[4,5]$. Their activities can cause discoloration, rotting, shrinking, seed necrosis, loss in germination capacity and toxification to oilseeds.
Al-Amod, [2] reported that the activities of fungi growing on stored groundnut seeds can reduce the germination rate beside the loss of carbohydrate, protein and total oil content, induce increased moisture content, free fatty acid content and enhancing other biochemical changes. Fungi continue to represent a major human health risk throughout the world and particularly in the humid tropics being major spoilage agents of food crops [6].

Manimurugan, [7] reported that disease transmission is usually carried out by seeds because they get associated with a number of pathogens either in the field or in storage. Seed - borne fungi were generally managed by the use of some synthetic chemicals which were also considered to be both efficient and effective [8]. The continuous use of synthetic fungicides unravelled its non-biodegradability and thereby having a residual toxicity to cause environmental pollution [9], therefore there is need for alternative safe means of control. Despite the fact that many pesticides such as persistent organic pollutants have been banned for over decades owing 
to their rigorous toxicity [10], excessive historical usage and environmental persistence still make them frequently detectable in the environment in high levels and can threaten ecological and public health [11-15]. However, attention has been given to the use of non-chemical systems for the treatment of the seed in order to protect it against plant pathogens [16]. Plant extracts have played significant role in inhibiting of seed-borne pathogens, improving seed quality and emergence of plant seeds [17]. There is now emphasis on use of botanicals such as the flowers, cloves, leaves, bark, root and seed extracts used for fungal control [18], these are considered as cheaper and safer means to the control of moulds. Therefore based on this, the foregoing study was aimed at controlling the fungal pathogens associated with the rot of groundnut seeds in Hong local government area of Adamawa state, Nigeria using mahogany bark and seeds.

\section{Methodology}

The inhibitory effect of Khaya senegalensis bark and oil extracts was carried out in the Medical Laboratory of Microbiology Department, Modibbo Adama University of Technology, Yola Adamawa State, Nigeria.

\section{Source of isolates}

Fungal isolates were isolated from 50 unhealthy groundnut seeds of two genotypes valencia (fastigiata) and peruvian (hirsuta) collected from one (1) major market in each of the seven (7) districts of Hong local government namely Hildi, Kulinyi, Dugwaba, Uba, Gaya, Pella, and Hong.

\section{Preparation of extracts}

The method of Ijato, et al. [19], was used to prepare both aqueous and ethanol extracts. Bark of Khaya senegalensis was collected (Figure 1) rinsed thoroughly under running tap water and was allowed to air dry for seven (7) days; this was then ground using pestle and mortar. Hundred (100), sixty (60) and twenty (20) grams were dissolved in $100 \mathrm{ml}$ of sterile distilled water and ethanol in separate conical flasks respectively. These were vigorously shaken and left to stand for 24 hours. The samples were then filtered with three layers' cheese cloth. The crude aqueous and ethanol extracts were evaporated through heating with a hot plate to complete dryness and concentrations of $100 \%, 60 \%$ and $20 \%$ were used.

Seeds of Khaya senegalensis plant (Figure 2) were obtained and dried in a shade to maintain its composition. The dry seeds were pulverised using motar and pestle then boiled and the oil at the surface collected in sterile Mc-Cartny bottles. Glycerol was used to vary the concentrations of the oils, $50 \%$, $60 \%, 70 \%, 80 \%, 90 \%$ and $100 \%$ of the Glycerol and Khaya senegalensis oil each.

\section{Inhibition level of bark extract and oil on the isolates}

The in-vitro test was carried out using the adopted method of Ijato, [19] to evaluate the inhibition level of the extract on

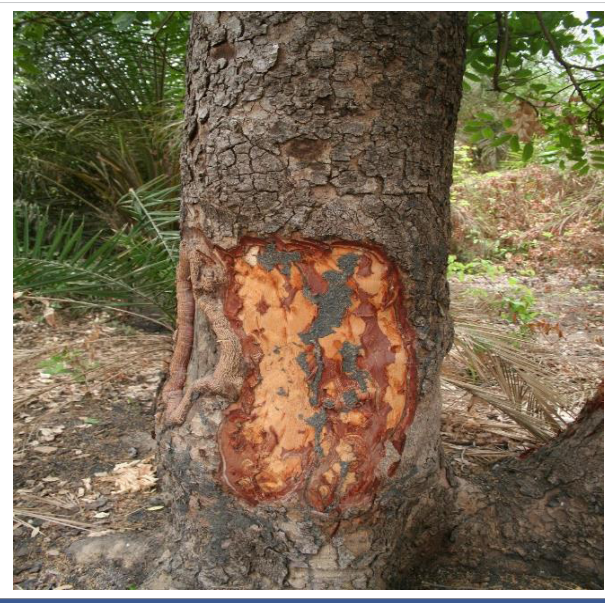

Figure 1: Khaya senegalensis Stem Bark.

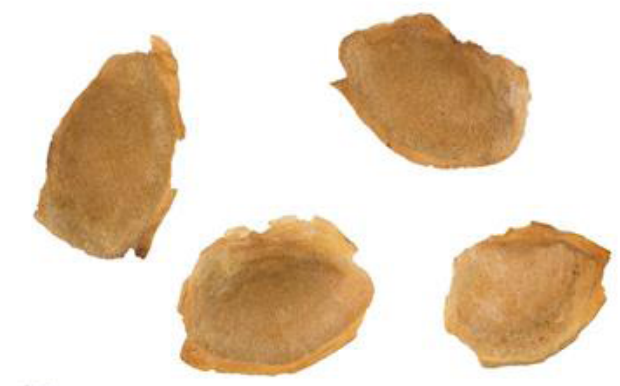

Figure 2: Khaya senegalensis Seeds.

fungal colony growth on $9 \mathrm{~cm}$ Petri dish. PDA mixed with the aqueous and ethanol leaf extracts was poured separately into each Petri dish in the different concentrations mentioned above, then followed by inoculation of the isolate. A mahogany extract free experiment was set up to serve as control. Radial growth inhibition was recorded using ruler for analysis. The in-vitro oil test was carried out by making wells with a $2 \mathrm{~mm}$ cork borer on the Potato Dextrose Agar and using a sterile $5 \mathrm{mls}$ syringe to inject the various concentrations into the wells. Growth of fungi was assessed through visual observation for lack of growth, scanty growth, moderate growth or luxuriant growth.

The in-vivo tests for bark and oil were carried out by placing cotton wool onto the plates then inserting three certified healthy seeds before inoculating a drop of mycelial/ spore suspension of each of the pathogens unto the seeds and also two (2) drops of the extracts (aqueous and ethanol) and oil with a sterile syringe. Dimension (inhibition level) of seed rot was recoded using thread and ruler.

\section{Statistical analysis}

All the data were analyzed using analysis of variance (ANOVA) according to Gomez and Gomez, [20]. Least Significant Difference (LSD) according to Scheff, [21] was used to separate the means that were significantly different. Statistical Analysis Software (SAS) Version 9.1 was used to analyze the results. 


\section{Result}

\section{Fungal isolates of groundnut in hong local government area}

The fungi were found to be associated with groundnuts in the seven (7) districts of Hong Local Government Area were; Aspergillus niger (brasiliensis), Aspergillus flavus, Penicillium chrysogenum, Rhizopus stolonifer, Pseudaiiescheria boydii, Paecilomyces lilacinus, Cylindrocarpon lichenicola and Scedosporium prolificans.

\section{Effect of aqueous and ethanol extracts of stem bark of mahogany on fungal growth}

In-vitro control trial using aqueous and ethanol extracts of Khaya senegalensis stem bark extract proved effective against the pathogens as there was a significant reduction in mycelial growth compared to control, however there was no significant variation between the aqueous and ethanol stem bark extracts (Table 1). The in-vivo test of Khaya sengalensis bark on the pathogens proved to be effective, however there was a significant difference between the aqueous and the ethanol bark extracts in which the ethanol extract reduced growth of the pathogens more than the aqueous. There was reduction in the mycelial growth of all the pathogens for aqueous and ethanol in-vitro, while in the in-vivo aqueous growth reduction was more in Penicillium chrysogenum, Pseudllescheria boydii,
Paecilomyces lilacinus and Scedosporium prolificans and as for the ethanol mycelial growth reduction was in Penicillium chrysogenum, Pseudallescheria boydii, Paecilomyces lilacinus and Scedosporium prolificans were the ones most effectively controlled.

Concentration of $20 \%$ was as effective as that of 100 as there was no significant difference in mycelial growth among the concentrations for the in-vitro trial. The concentration levels of the extracts produced variations on the control of the pathogens. The highest was at $100 \%$ concentration followed by the $60 \%$ concentration then $20 \%$ concentration, there was however no significant difference between $60 \%$ and $100 \%$ (Table 2).

Efficacy of stem bark extract on the pathogens showed there was a significant difference between the valencia and the peruvian. The local cultivar showed less susceptibility to fungal rot after treatment with the stem bark (Table 3).

Inhibitory effect of oil extract on the mycelial growth of pathogens

For all the pathogens except Rhizopus stolonifer there was no growth between $50 \%$ to $100 \%$ concentration of the Khaya senegalensis oil, however there was a luxuriant growth for the control that is $0 \%$ for the oil. At $50 \%$ concentration of the oil

Table 1: Aqueous and Ethanol Growth inhibition of Stem-Bark Extracts of Khaya senegalensis on Pathogens of Stored Groundnut (mm) in Hong Local Government Area of Adamawa State, Nigeria.

\begin{tabular}{|c|c|c|c|c|c|c|c|c|}
\hline \multicolumn{9}{|c|}{ Pathogens } \\
\hline & $\begin{array}{l}\text { Aspergillus } \\
\text { brasilensis }\end{array}$ & $\begin{array}{l}\text { Aspergillus } \\
\text { flavus }\end{array}$ & $\begin{array}{c}\text { Penicillium } \\
\text { chrysogenum }\end{array}$ & $\begin{array}{l}\text { Rhizopus } \\
\text { stolonifer }\end{array}$ & $\begin{array}{l}\text { Pseudaiiescheria } \\
\text { boydii }\end{array}$ & $\begin{array}{c}\text { Paecilomyces } \\
\text { lilacinus }\end{array}$ & $\begin{array}{c}\text { Cylindrocarpon } \\
\text { lichenicola }\end{array}$ & $\begin{array}{l}\text { Secdosporium } \\
\text { prolificans }\end{array}$ \\
\hline & \multicolumn{8}{|c|}{ In-vitro (mycelial growth in $\mathrm{mm}$ ) } \\
\hline Solvent & & & & & & & & \\
\hline Aqueous & 19.17 & 17.83 & 17.00 & 23.83 & 15.67 & 16.58 & 17.25 & 22.25 \\
\hline Ethanol & 5.56 & 8.67 & 8.40 & 12.09 & 6.43 & 7.11 & 5.59 & 10.64 \\
\hline Control & 72.67 & 68.00 & 65.33 & 88.67 & 60.67 & 64.00 & 67.33 & 85.33 \\
\hline \multirow[t]{2}{*}{ LSD } & 23.67 & 23.58 & 22.00 & 28.50 & 19.08 & 20.42 & 20.17 & 27.75 \\
\hline & & & & & In-vivo & & & \\
\hline \multicolumn{9}{|l|}{ Solvent } \\
\hline Aqueous & 25.83 & 26.63 & 18.58 & 28.86 & 13.21 & 13.58 & 13.25 & 12.96 \\
\hline Ethanol & 15.33 & 15.46 & 11.96 & 20.58 & 9.25 & 11.54 & 11.58 & 11.04 \\
\hline Control & 55.00 & 55.00 & 42.50 & 78.33 & 34.17 & 43.33 & 44.17 & 42.50 \\
\hline LSD & 3.68 & 3.61 & 2.81 & 3.59 & 2.44 & 2.54 & 3.64 & 2.95 \\
\hline
\end{tabular}

Table 2: Inhibitory Effect of Concentration of Stem-Bark Extracts on Pathogens ( $\mathrm{mm}$ ) in Hong Local Government Area of Adamawa State, Nigeria.

\begin{tabular}{|c|c|c|c|c|c|c|c|c|}
\hline \multicolumn{9}{|c|}{ Pathogens } \\
\hline & $\begin{array}{l}\text { Aspergillus } \\
\text { brasilensis }\end{array}$ & $\begin{array}{l}\text { Aspergillus } \\
\text { flavus }\end{array}$ & $\begin{array}{c}\text { Penicillium } \\
\text { chrysogenum }\end{array}$ & $\begin{array}{l}\text { Rhizopus } \\
\text { stolonifer }\end{array}$ & $\begin{array}{c}\text { Pseudaiiescheria } \\
\text { boydii }\end{array}$ & $\begin{array}{l}\text { Paecilomyces } \\
\text { lilacinus }\end{array}$ & $\begin{array}{l}\text { Cylindrocarpon } \\
\text { lichenicola }\end{array}$ & $\begin{array}{l}\text { Secdosporium } \\
\text { prolificans }\end{array}$ \\
\hline Concentration (\%) & \multicolumn{8}{|c|}{ In-vitro (mycelial growth in $\mathrm{mm}$ ) } \\
\hline 20 & 8.33 & 9.50 & 7.33 & 10.50 & 5.67 & 6.17 & 5.00 & 9.50 \\
\hline 60 & 3.00 & 3.33 & 3.17 & 3.50 & 2.18 & 2.50 & 1.83 & 3.67 \\
\hline 100 & 1.67 & 2.00 & 2.17 & 2.00 & 1.00 & 1.33 & 0.67 & 1.50 \\
\hline LSD & 7.86 & 12.26 & 11.87 & 17.10 & 9.09 & 10.05 & 7.91 & 15.05 \\
\hline Concentration (\%) & & & & & In-vivo & & & \\
\hline 20 & 13.17 & 15.17 & 8.67 & 9.83 & 5.50 & 3.75 & 3.00 & 3.17 \\
\hline 60 & 8.50 & 8.17 & 6.08 & 6.75 & 3.00 & 2.08 & 1.17 & 1.50 \\
\hline 100 & 5.67 & 5.83 & 3.83 & 4.00 & 2.25 & 1.08 & 0.83 & 0.83 \\
\hline LSD & 5.21 & 5.11 & 3.97 & 5.08 & 3.45 & 3.60 & 5.14 & 4.18 \\
\hline
\end{tabular}

LSD: Least Significant Difference 
Table 3: Effect of Stem-Bark Extract on Pathogen/Groundnut Variety $(\mathrm{mm})$ in Hong Local Government Area of Adamawa State, Nigeria.

\begin{tabular}{|c|c|c|c|c|c|c|c|c|}
\hline \multicolumn{9}{|c|}{ Pathogen } \\
\hline & $\begin{array}{l}\text { Aspergillus } \\
\text { brasillensis }\end{array}$ & $\begin{array}{l}\text { Aspergillus } \\
\text { flavus }\end{array}$ & $\begin{array}{c}\text { Penicillium } \\
\text { chrysogenum }\end{array}$ & $\begin{array}{l}\text { Rhizopus } \\
\text { stolonifer }\end{array}$ & $\begin{array}{l}\text { Pseudaiiescheria } \\
\text { boydii }\end{array}$ & $\begin{array}{c}\text { Paecilomyces } \\
\text { lilacinus }\end{array}$ & $\begin{array}{l}\text { Cylindrocarpon } \\
\text { lichenicola }\end{array}$ & $\begin{array}{l}\text { Scedosporium } \\
\text { prolificans }\end{array}$ \\
\hline Variety & \multicolumn{8}{|c|}{ (mycelial growth in $\mathrm{mm}$ ) } \\
\hline Valencia & 24.50 & 28.71 & 19.96 & 30.08 & 16.63 & 14.21 & 15.96 & 15.00 \\
\hline Peruvian & 16.67 & 13.38 & 10.58 & 19.38 & 5.83 & 10.92 & 8.88 & 9.00 \\
\hline LSD & 3.09 & 3.61 & 2.81 & 3.59 & 2.44 & 2.54 & 3.64 & 2.95 \\
\hline
\end{tabular}

LSD: Least Significant Difference

Rhizopus stolonifer showed luxuriant growth while between $60 \%-80 \%$ its growth was reduced to moderate and became scanty between $90 \%-100 \%$ (Table 4 ).

In-vivo control trial with oil of Khaya senegalensis at $50 \%$ produced scanty to moderate growth for all the pathogens except Rhizopus stolonifer which produced moderate growth at $50 \%$ while at $100 \%$ growth was scanty to none and control has full coverage on the peruvian variety (Table 5), however all pathogens showed full coverage on the seeds of valencia variety with Aspergillus niger and Rhizopus stolonifer having total coverage though Pseudaiiescheria boydii and Cylindrocarpon lichenicola were effectively inhibited and showed no growth at the $50 \%$ and $100 \%$, there was no coverage at $100 \%$ except for Aspergillus flavus that was moderate and Rhizopus stolonifer with moderate coverage as well, as for the control there was complete coverage on the seeds for all the pathogens (Table 6).

\section{Discussion}

Results showed that the mahogany stem-bark and oil were effective in the control of fungal pathogens of groundnut seeds. The results was in agreement with the work of Abdulsalam, et al. [22], who reported treatment with different concentration of plant extracts revealed that Khaya senegalensis A Juss. Extract highly retarded the vegetative growth of the fungi responsible for the neck rot disease of onions. It is similar with the work of Liman, et al. [23], but on different organism who confirmed that mahogany extract was highly effective on the control of Root knot disease of tomatoes caused by nematodes. A report by [24] stated that a plant may have different concentrations of a chemical in different vegetal parts; roots, leaves, flowers and fruit and may even be absent in one or more parts. According to Khare, et al. [25], plant essential oil is a useful source of antifungal compounds and the effectiveness of Khaya senegalensis oil in controlling fungal pathogen could probably be due to constituents of secondary metabolite capable of controlling and inhibiting the pathogens. O'Bryne, et al. [26] reported that the fresh and dried mahogany bark extracts have also shown strong antimicrobial properties.

This work also conforms to the work of Bamaiyi, et al. [27], who have shown that tuber treatment with Khaya senegalensis bark extract can be used for controlling potato tuber soft rot disease. Abdelgaleil, et al. [17] reported that the extract from the dried bark was more effective than that from the fresh bark. Probably the active compounds are more concentrated in the dried bark than in the fresh bark which contains a higher water content at the time of the extract preparation.
Table 4: Effect of Khaya senegalensis Oil on Fungal Pathogens of Groundnut In -vitro in Hong Local Government Area of Adamawa State, Nigeria.

\begin{tabular}{|c|c|c|c|c|c|c|c|c|}
\hline \multirow[t]{2}{*}{ Pathogen } & \multicolumn{8}{|c|}{ Concentrations } \\
\hline & $50 \%$ & $60 \%$ & $70 \%$ & $80 \%$ & $90 \%$ & $100 \%$ K.s & $100 \% \mathrm{G}$ & Control \\
\hline Aspergillus brasillensis & + & - & - & - & - & - & - & +++ \\
\hline Aspergillus flavus & + & - & - & - & - & - & - & +++ \\
\hline Penicillium chrysogenum & + & - & - & - & - & - & - & +++ \\
\hline Rhizopus stolonifera & +++ & ++ & ++ & ++ & ++ & + & + & +++ \\
\hline Pseudaiiescheria boydii & - & - & - & - & - & - & - & +++ \\
\hline Paecilomyces lilacinus & - & - & - & - & - & - & - & +++ \\
\hline $\begin{array}{c}\text { Cylindrocarpon } \\
\text { lichenicola }\end{array}$ & - & - & - & - & - & - & - & +++ \\
\hline $\begin{array}{l}\text { Scedosporium } \\
\text { prolificans }\end{array}$ & - & - & - & - & - & - & - & +++ \\
\hline
\end{tabular}

Key: - No Growth; + Scanty Growth; ++ Moderate Growth: +++ Luxuriant Growth; K.s Khaya senegalensis; G Glycerol

Table 5: Effect of Khaya senegalensis Oil on Growth of Pathogen on Groundnut Seed In-vivo On Peruvian Variety (\%) in Hong Local Government Area of Adamawa State, Nigeria.

\begin{tabular}{|c|c|c|c|}
\hline Pathogens & \multicolumn{3}{|c|}{ Concentrations } \\
\hline Aspergillus brasillensis & $50 \%$ & $100 \%$ & Control \\
\hline Aspergillus flavus & 20 & 20 & 40 \\
\hline Penicillium chrysogenum & 40 & 20 & 40 \\
\hline Rhizopus stolonifera & 20 & - & 20 \\
\hline Pseudaiiescheria boydii & 40 & 20 & 60 \\
\hline Paecilomyces lilacinus & - & - & 20 \\
\hline Cylindrocarpon lichenicola & - & - & 40 \\
\hline Scedosporium prolificans & - & - & 20 \\
\hline
\end{tabular}

Table 6: Effect of Khaya senegalensis Oil on Growth of Pathogen in-vivo for Valencia Variety (\%) in Hong Local Government Area of Adamawa State, Nigeria.

\begin{tabular}{|c|c|c|c|}
\hline Pathogens & \multicolumn{3}{|c|}{ Concentrations } \\
\hline & $50 \%$ & $100 \%$ & Control \\
\hline Aspergillus brasilensis & 20 & 20 & 60 \\
\hline Aspergillus flavus & 40 & 20 & 40 \\
\hline Penicillium chrysogenum & 20 & - & 40 \\
\hline Rhizopus stolonifera & 40 & 20 & 70 \\
\hline Pseudaiiescheria boydii & - & - & 20 \\
\hline Paecilomyces lilacinus & - & - & 20 \\
\hline Cylindrocarpon lichenicola & - & - & 20 \\
\hline Scedosporium prolificans & - & - & 20 \\
\hline
\end{tabular}

The soaking of the fresh bark in water might have further diluted the concentration of the active substance compared to the soaking of the powder from the dried bark. Although, there are few reports on the use of Khaya senegalensis products in controlling plant pathogens, extracts from the plant have been extensively used in the control of insect pests of crops, particularly cotton boll worm, apart from the insecticidal properties of Khaya senegalensis products, these products have also been reported to possess antifungal and bactericidal properties. 


\section{Conclusion}

This research work has proven that mahogany extract (bark and oil) can suppress the growth of fungal pathogens isolated from groundnut. Therefore continued trails should be carried out on the field and in different locations. Furthermore, research should be conducted to determine the active compound responsible for fungal growth inhibitor and the result will be communicated to farmers through agricultural extension agents.

\section{References}

1. Weiss EA. Oilseed Crops. $2^{\text {nd }}$ edition. Blackwell Science Ltd., Oxford, London, Berlin Carlton, Paris. 2000; 31-36.

2. Al-Amod MO. Seed-borne fungi of some peanut varieties from Hadhramout and Abyan Governorates in Yemen. Int J Agri Technol. 2015; 11: 1359-1370.

3. Osman RA. Occurrence and Identitication of Seed Borne Fung Associated with Groundnuts in Kordofan States. A Thesis Submitted in Partial Fulfillment of the Requirements for the M.Sc. Degree in Plant Protection. Sudan University of Science and Technology College of Graduate Studies and Scientific Research University of Zalingei. 2016.

4. Elwakil MA, El-Metwally MA. Seed-borne Fungi of Peanut in Egypt; Pathogenicity and Transmission. Pakistan of Biological Science. 2001; 4: 63-68

5. Chavan AM, Kakde RB. Studies on abnormal oilseeds mycoflora from Marathwada region. Bionano Frontier. 2008; 2: 101-104.

6. Olusegun A, Hussaini AM, Isaac MO, Mojisola E, Kingsley Ol, et al Fungal and Mycotoxin Contamination of Nigerian Foods and Feeds: in Mycotoxin and Food Safety in Developing Countries, edited by Hussaini Anthony Makun, ISBN 978-953-51-1096-5. 2013.

7. Manimurugan C. Pathogen Free Seed Production in Black Gram (Vigna mungo (L.) Hepper). M.sc. (Ag.) Thesis, Tamil Nadu Agricultural University, Coimbatore, Tamil Nadu. 2003.

8. Ahmad I, Beg A. Antimicrobial phytochemical studies on 45 Indian medicinal plants against multi-drug resistant human pathogens. $J$ Ethno Pharmacy. 2007; 7: 113-123.

PubMed: https://www.ncbi.nlm.nih.gov/pubmed/11167029

9. Ajobade TA, Amusa A. Evaluation of antifungal efficacy of some plant extract on cusvularia. Lunate the causal organisms of leaf spot. African J Environ Sci Technol. 2001; 4: 1010

10. Jennings AA, Li Z. Residential surface soil guidance applied worldwide to the pesticides added to the Stockholm Convention in 2009 and 2011. J Environmental Manag. 2015; 160: 226-240. PubMed: https://www.ncbi.nlm.nih.gov/pubmed/26144561

11. Fantke $P$, Juraske $R$, Antón $A$, Friedrich $R$, Jolliet $O$. Dynamic multicrop model to characterize impacts of pesticides in food. Environ Sci Technol. 2011; 45: 8842-8849.

PubMed: https://www.ncbi.nlm.nih.gov/pubmed/21905656

12. Fantke $P$, Friedrich $R$, Jolliet $O$. Health impact and damage cost assessment of pesticides in Europe. Environ Int. 2012; 49: 9-17. PubMed: https://www.ncbi.nlm.nih.gov/pubmed/22940502

13. Odukkathil G, Vasudevan, N. Residues of endosulfan in surface and subsurface agricultural soil and its bioremediation. J Environ Manag. 2016; 165: 72-80. PubMed:

https://www.ncbi.nlm.nih.gov/pubmed/26413801

14. Orton TG, Saby NPA, Arrouays D, Jolivet CC, Villanneau EJ, et al. Spatial distribution of lindane concentration in topsoil across France. Sci Total Environ. 2013; 443: 338-350.

PubMed: https://www.ncbi.nlm.nih.gov/pubmed/23202380

15. Li Z, Jennings A. Global variations in pesticide regulations and health risk assessment of maximum concentration levels in drinking water J Environ Manag. 2018; 212: 384-394.

PubMed: https://www.ncbi.nlm.nih.gov/pubmed/29455146

16. Ademola IO, Fagbemi BO, Idowu SO. Evaluation of antihelminthic activity of Khaya senegalensis extracts against gastro intestinal nematodes of sheep: in vitro and in vivo studies. Vet Parasitol. 2004; 122: 151-164. PubMed: https://www.ncbi.nlm.nih.gov/pubmed/15177720

17. Abdelgaleil SAM, Iwagawa $T$, Doe $M$, Nakatani $M$. Antifungal limonoids from the fruits of Khaya senegalensis. Fitoterapia. 2004; 75: 566-572. PubMed: https://www.ncbi.nlm.nih.gov/pubmed/15351110

18. Abdelgaleil SAM, Okamura H, Iwagawa $\mathrm{T}$, Sato A, Miyihara I, et al. Khayanolides rearranged phragmalin limonoid antifeedants from Khaya senegalensis. Tetrahedron. 2001; 57: 119-126.

19. Ijato JY, Otoide JE, Ijadunola JA, Aladejimokun AO. Efficacy of antimicrobial effect of Venonia amygdalina and Tridax procumbens in in vitro control of tomato (Lycopersicum esculentum) post -harvest fruit rot. Report and Opinion. 2011; 3: 120-123.

20. Gomez KA, Gomez AA. Statistical Procedure for Agriculi tural Research. 2nd ed. Wiley. 1984; 680.

21. Scheff HA. Method of judging all contrast in the Analysis of Variance. Biometric. 1953; 40: 104-107.

22. Abdulsalam AA, Zakari BG, Chimbekujwo IB, Channya FK, Bristone B. Isolation and Control of Fungi Associated with Neck Rot Disease of Onions (Allium cepa L.) In Bama, Borno State, Nigeria. Global Journal of Biology, Agriculture and Health Sciences. 2015; 4: 35-39.

23. Liman IB, Ibrahim S, Rabah NT. The efficacy of Mahogany leaf extract on Root knot nematode disease of tomato (Lycopersicon esculentum). Nigerian J Basic and Applied Sciences. 2010; 18: 272-276.

24. Montes BR. Natural Plant Products to Combact Pathogens. Mexican J Phytopathol. 1996; 14: 9-14.

25. Khare NP, Lucas B, Seavey KC, Liu YA, Sirohi A, et al. Steady State and Dynamic Modeling of Gas-Phase Polypropylene Processes using Stirred-Bed Reactors. Ind Eng Chem Res. 2004; 43: 884.

26. O'Bryne DJ, Knauft DA, Shireman RB. Low fat monounsaturated rich diets containing high-oleate peanuts improve serum lipoprotein profiles. Lipids. 1997; 32: 687-695.

PubMed: https://www.ncbi.nlm.nih.gov/pubmed/9252956

27. Bamaiyi LJ, Ndams IS, Toro WA, Odekina S. Effect of mahogany (Khaya senegalensis) seed oil in control of Callosobruchus maculatus on stored cowpea. Plant Protect Sci. 2006; 42: 130-134. 